\title{
Clinical, Laboratory, and Radiological Evaluation of 32 Cases with Tuberculous Meningitis
}

\section{Tüberküloz Menenjitli 32 Olgunun Klinik, Laboratuvar ve Radyolojik Deg̃erlendirmesi}

\author{
İem AKDEMIR KALKAN,(ID)!, Rușen ACU \\ ${ }^{1}$ Department of Infectious Diseases and Clinical Microbiology, Faculty of Medicine, University of Ankara, Ankara, Turkey \\ 2 Department of Radiology, Cerrahpasa Faculty of Medicine, University of Istanbul, Istanbul, Turkey \\ ${ }^{3}$ Department of Infectious Diseases and Clinical Microbiology, Faculty of Medicine, University of Sanko, Gaziantep, Turkey \\ ${ }^{4}$ Department of Infectious Diseases and Clinical Microbiology, Faculty of Medicine, University of Dicle, Diyarbakir, Turkey
}

* The study has been presented previously as an oral presentation in $3^{\text {rd }}$ South Anatolia Infection Congress, 1-5 May 2019, Diyarbakir, Turkey.

Cite this article as: Akdemir Kalkan I, Acu R, Çınar G, Ayaz C, Tekin R. Clinical, laboratory, and radiological evaluation of 32 cases with tuberculous meningitis. FLORA 2019;24(4):353-60.

\begin{abstract}
Introduction: Tuberculous meningitis is an important central nervous system infection, and it is the most severe clinical form of tuberculosis. Mycobacterium tuberculosis is the frequently isolated microorganism, and it is associated with high morbidity and mortality among central nervous system infections. Despite all the advances in medicine, diagnosis of tuberculous meningitis is still a significant problem. In our study, we aimed to evaluate clinical, microbiological and radiological features of the patients with tuberculous meningitis in detail.

Materials and Methods: The study was designed as a retrospective study. A total of 32 patients diagnosed on the basis of clinical, microbiological and radiological criteria with tuberculous meningitis were included into the study. Patients were exposed to computed tomography scan and magnetic resonance imaging with the exception of two patients. Computed tomography scans were performed at the time of admission to the emergency department while magnetic resonance imagings were performed within the 48 hours after computed tomography scans. The data were analyzed with SPSS 24.
\end{abstract}

Results: Eleven of the patients were diagnosed with gold standard methods. The pathogen microorganism was M. tuberculosis in all cases. The diagnoses of other patients were determined by clinical; microbiologic and radiologic estimations. Demographic findings-symptoms of the patients, laboratory findings-symptoms and the contribution of radiology to the diagnosis were evaluated. Particularly, when the contribution of radiology to the diagnosis was studied, it was found that especially magnetic resonance imaging was more useful than computed tomography.

Conclusion: Central nervous system infections due to M. tuberculosis are frequently related to high morbidity and mortality. The gold diagnosis methods of the disease are; isolation of M. tuberculosis from the cerebrospinal fluid or seeing the microorganism in the fluid with EZN stain. Because of the low positivity rates in gold standard methods, radiologic methods such as magnetic resonance imaging can be used in tuberculous meningitis diagnosis.

Key Words: Meningeal infections; Tuberculous meningitis; Computed tomography; Magnetic resonance imaging

Received/Geliș Tarihi: 29/05/2019 - Accepted/Kabul Ediliș Tarihi: 26/06/2019

${ }^{\bullet}$ Copyright 2019 by Flora. Available on-line at www.floradergisiorg. 


\title{
öz
}

\section{Tüberküloz Menenjitli 32 Olgunun Klinik, Laboratuvar ve Radyolojik Deg̃erlendirmesi}

\author{
İrem AKDEMIR KALKAN ${ }^{1}$, Rușen ACU², Güle ÇINAR', Celal AYAZ³ ${ }^{3}$, Recep TEKiN ${ }^{4}$
}

\footnotetext{
${ }^{1}$ Ankara Üniversitesi Tıp Fakültesi, İnfeksiyon Hastalıkları ve Klinik Mikrobiyoloji Anabilim Dalı, Ankara, Türkiye

2 İstanbul Üniversitesi Cerrahpașa Tıp Fakültesi, Radyoloji Anabilim Dalı, İstanbul, Türkiye

${ }^{3}$ Sanko Üniversitesi Tıp Fakültesi, İnfeksiyon Hastalıkları ve Klinik Mikrobiyoloji Anabilim Dalı, Gaziantep, Türkiye

${ }^{4}$ Dicle Üniversitesi Tıp Fakültesi, İnfeksiyon Hastalıkları ve Klinik Mikrobiyoloji Anabilim Dalı, Diyarbakır, Türkiye
}

Giriş: Tüberküloz menenjit önemli bir santral sinir sistemi infeksiyonudur ve tüberkülozun en ağır klinik formudur. Mycobacterium tuberculosis en sık izole edilen mikroorganizmadır ve santral sinir sistemi infeksiyonları içinde önemli bir mortalite ve morbidite nedenidir. Tıptaki tüm gelişmelere rağmen tüberküloz menenjit tanısı koymak hala ciddi bir problemdir. Bu çalısmada tüberküloz menenjit tanısı alan hastaların klinik, laboratuvar ve radyolojik özelliklerini detaylıca incelemeyi amaçladık.

Materyal ve Metod: Çalısma retrospektif olarak tasarlandı. Klinik, mikrobiyolojik ve de radyolojik olarak tüberküloz menenjit tanısı alan toplam 32 hasta çalısmaya dahil edildi. iki hasta dışındaki tüm hastalara hem bilgisayarlı tomografi (BT) hem de manyetik rezonans görüntüleme (MRG) ile kraniyal görüntüleme yapıldı. Bilgisayarı tomografi incelemeleri acil serviste, MRG incelemeleri ise BT'den sonraki 48 saat içinde yapıldı. Data analizi SPSS.24 ile gerçekleştirildi.

Bulgular: Hastaların $11^{\prime} i$ altın standart yöntemler ile tanı almıştır. Üretilen tüm etkenler M. tuberculosis'dir. Diğer hastaların tanısı ise klinik, laboratuvar ve radyoloji desteği ile konulmuştur. Hastalara ait demografik veriler, semptomlar, laboratuvar bulguları ve radyoıojinin tanıya katkısı değerlendirilmiştir. Radyolojinin tanıya katkısı incelendiğinde MRG BT'ye göre tanıya daha fazla katkı sağlayıcı olarak bulunmuştur.

Sonuç: M. tuberculosis'e bağlı santral sinir sistemi infeksiyonları yüksek mortalite ve morbidite nedenidir. Tanı için altın standart, basilin EZN boyası ile gösterilmesi ve kültürde üretilmesidir. Bu yöntemlerle düşük pozitiflik oranlarının olması nedeniyle radyolojik yöntemler özellikle de MRG tanıya yardıma yöntem olarak kullanılabilir.

Anahtar Kelimeler: Tüberküloz menenjit; Meningeal infeksiyonlar; Manyetik rezonans görüntüleme; Bilgisayarlı tomografi

\section{INTRODUCTION}

Tuberculosis (TB) is a major public health problem that maintains its importance all over the world. Despite the advances made in its diagnosis and treatment, it is nevertheless a disease that has a high mortality and morbidity rate because the cases are typically diagnosed late and pose complications ${ }^{[1]}$.

Although the disease is most commonly exhibited as pulmonary TB, extrapulmonary TB can affect almost all systems. Central nervous system (CNS) TB has the highest mortality and morbidity rates amongst all cases of extrapulmonary $\mathrm{TB}$, most of which are diagnosed as tuberculosis meningitis $(\mathrm{TBM})^{[2]}$.

In this serious clinical picture, certain factors affect prognosis of the patients. One of the most important of these factors is the patient's level of consciousness when diagnosed. Administering patients with early treatment also affects the mortality rate of the disease. Despite all developing microbiological diagnostic methods, especially those for CNS TB, difficulties are still encountered in early diagnosis with methods known as gold standards ${ }^{[2]}$. Although patients' clinical symptoms are compatible with meningitis, distinguishing between bacterial meningitis and TBM based on cerebrospinal fluid (CSF) taken at the time of admission is difficult to perform. Meningitis is not easily detected by the staining method for acidfast bacilli (AFB) testing. Nevertheless, the production of the microbial agent in a culture medium takes a considerable amount of time, even when working with automatized systems. Difficulty and lengthy waiting time of diagnosis lead to a delay in the final diagnosis and, hence, the patients' treatment. Difficult diagnosing and long waits for 
a diagnosis lead to a delay in diagnosis and patient treatment, which then adversely affects the course of a disease that is already quite serious. Molecular tests, such as a polymerase chain reaction from CSF for TBM, have demonstrated rather different sensitivity and specificity rates in various studies although advances of molecular methods in microbiology have provided diagnostic ease and speed for the diagnosis of many diseases. Therefore, these molecular tests are not yet widely accepted as successful diagnostic methods ${ }^{[3]}$. Another limitation of the molecular techniques is their lack of availability. Therefore, diagnostic difficulties lead clinicians to search for alternative methods for diagnosing $\mathrm{TBM}^{[4]}$.

CNS imaging methods also play a very important role in the diagnosis and follow-up of infections resulting from other diseases ${ }^{[2]}$. Radiological examinations are substantial for clinicians in evaluating possible complications and in following up with treatment while waiting for the results of further tests in cases in whom a clear result cannot be obtained with baseline CSF analysis ${ }^{[5]}$. A computed tomography (CT) examination, which is frequently employed to perform the lumbar puncture (LP)-especially when initially determining a diagnosis -in patients who receive an MRI for the pre-diagnosis of meningitis is a less commonly used imaging method in patients. MRI is more sensitive than CT and highly specific for pathologies involving CNS since non-ionizing radiation from MRI provides more information about high soft-tissue contrast and anatomical details. The likelihood of a lethal allergic reaction to the contrast agent used during MRI is significantly lower than that of the agents used in CT. In addition, the structures that cannot be assessed due to bone artefacts that are found during CT are easily distinguishable through $\mathrm{MRI}^{[6,7]}$. Further, unless a contraindication exists, the administration of a contrast agent provides important contributions toward distinguishing pathological features and assessing possible complications. Therefore, an MRI scan with a contrast agent should be preferred in every suitable case for imaging procedures planned for CNS infection.

Early-stage MRI in identifying a CNS infection may play an important role in deciding their proper treatment. In this study, we aimed to evaluate clinical and CSF findings as well as reveal the contribution these imaging modalities make to early diagnosis by reviewing MRI and CT imaging findings in patients with TBM.

\section{MATERIALS and METHODS}

The study was retrospectively planned and involved 32 patients followed up at the Department of Infectious Diseases and Clinical Microbiology, Faculty of Medicine at Dicle University. Demographic data, clinical characteristics, laboratory results, and radiological imaging results of 32 TBM patients were recorded between January 2009 and May 2013 based on the TBM follow-up form in the patients' files.

The criteria for inclusion in the study were that patients had received a pre-diagnosis of TBM and had then received TBM treatment with a definitive or clinical diagnosis. Based on medical history, physical examination findings (fever, headache, nausea, vomiting, nuchal rigidity, Kernig and Brudzinski signs, convulsions, presence of regional neurological signs) and CSF findings (pressure, appearance, cell number and type, CSF protein and glucose levels), Gram and Giemsa stainings of CSF, CSF culture, and clinical and radiological follow-up of patients with meningitis, a pre-diagnosis of TBM was determined.

The AFB detection in an Ehrlich Ziehl-Neelsen stain of CSF and/or the production of Mycobacterium tuberculosis in a Löwenstein-Jensen medium were/was accepted as a definitive diagnostic criterion. Strong findings supporting TB in patients' medical history, CSF findings, and radiological examinations were accepted as a clinical diagnosis. The patients were clinically staged according to the recommendations of the British Medical Research Council (BMC) at the time of admission.

All patients who participated in the study were subjected to $\mathrm{CT}$, with the exception of one patient who was pregnant. All patients were subjected to MRI, with the exception of one patient whose general condition was not considered appropriate for MRI. CT scans were performed at the time of admission to the emergency department, while MRI scans were performed within 
48 hours following the CT scans. The CT and MRI scans that would later be compared were determined as the scans performed using contrast material within the first 48 hours of patient admission.

Ethics approval was obtained from the Ethics Committee of the Dicle University Medical Faculty (Approval no. 287), and SPSS Statistical Package ${ }^{\circledR} 21.0$ was used to analyze the data.

\section{RESULTS}

The 32 patients chosen and included in the study were those diagnosed with TBM and who received treatment based on their pre-diagnosis and clinical symptoms. Of the 32, 40.6\% ( $\mathrm{n}=$ 13) were female and $59.4 \%(n=19)$ were male. The average age among all patients was 37.4 years.

$21.9 \%$ of the patients $(n=7)$ had a previous history of TB, $15.6 \%(n=5)$ had a family history of TB, and $25 \%(n=8)$ had a history of being in physical contact with a TB patient. The shortest complaint duration was 3 days, with a median complaint duration of 24.1 days at the time of admission. All patients reported headache while $75 \% \quad(n=24)$ additionally experienced nausea and vomiting. In the examinations, Kerning was detected in 5 patients (15.6\%) and Brudzinski was detected in 7 (21.9\%) while 25 (78.1\%) experienced nuchal rigidity and 26 (87.5\%) experienced fever. Rash was detected in 3 patients (9.4\%) while 5 (15.6\%) experienced convulsions at the time of admission. Eleven (34.4\%) patients were identified as Stage 1, 12 (37.5\%) Stage 2, and $9(28,1 \%)$ Stage 3 according to the BMC neurological staging system.

CSF pressures were determined subjectively based on the flow rate of CSF when LP was performed. CSF pressure was normal in 5 patients (15.6\%) and had increased in 26 (81.3\%). CSF was not obtained from one patient due to an anatomical defect (this patient was diagnosed by MRI).

The appearance of $14(43.8 \%)$ of the 31 CSF samples were clear, 14 (43.8\%) were xanthochromic, and 3 (9.4\%) were blurred. CSF cell counts were found to be a minimum of $20 / \mathrm{mm}^{3}$ cells and a maximum of $2400 / \mathrm{mm}^{3}$ cells, with a mean cell number of $725 / \mathrm{mm}^{3}$. CSF protein value $[46.9 \%(n=15)]$ could not be measured due to its expression of a very high value in these patients. In the remaining 16 samples (53.1\%), the ratio of CSF micro total protein was $>45$ $\mathrm{mg} / \mathrm{dL}$, and mean CSF protein was $175.8 \mathrm{mg} /$ $\mathrm{dL}$. The CSF glucose value was between $4 \mathrm{mg} /$ $\mathrm{dL}$ and $62 \mathrm{mg} / \mathrm{dL}$, with a mean value of 28 $\mathrm{mg} / \mathrm{dL}$. All patients had at least twice amount higher blood glucose levels than CSF glucose levels. In baseline CSF evaluation, CSF peripheral spread and gram staining were performed for all patients. The ratio of the patients diagnosed by AFB positivity was $6.3 \%(n=2)$ while no bacterial agent was detected in any patients. Eleven patients [37.5\% $(n=11)$ ] had $M$. tuberculosis produced in the culture medium. In a patient whose AFB stain detected bacilli, the bacillus was also expressed bacillus in the culture medium. These patients were accepted as definitive diagnosis. Furthermore, all patients included in the study tested negative for HIV.

Pathological and radiological findings that were valuable in terms of TBM diagnosis and patient follow-up were classified into the five main categories of gyrus involvement, hydrocephalus, tuberculoma, exudate in the basal cisterns, and brain infarction.

At least one pathological finding from CT tomography was identified in 12 (38.7\%) patients. Of these findings, infarction was identified in 2 (6.3\%) patients, gyrus involvement in $3(9.7 \%)$, hydrocephalus in 11 (34.4\%), and tuberculoma in $2(6.5 \%)$. None of the patients had exudates either in basal cisterns or in a sylvian fissure on their CT scans, while 5 (16.1\%) patients expressed multiple findings of cranial CT.

Pathological findings were determined through MRI in 24 (77.4\%) patients. These findings were hydrocephalus in 14 [45.2\% $(n=14)]$, exudate in basal cisterns in 10 [32.3\% $(n=10)]$, exudate in sylvian fissure in 4 [12.9\% $(n=4)]$, infarction in $8[25.8 \%(n=8)]$, and gyrus involvement in 18 [56.3\% ( $n=18)]$. Tuberculoma was detected through MRI in 10 patients [32.3\% $(n=10)$ ], while 15 [48.4\% ( $n=15)$ ] had multiple radiological findings. We expressed the patients' demonstrative radiological images alongside their explanations in 

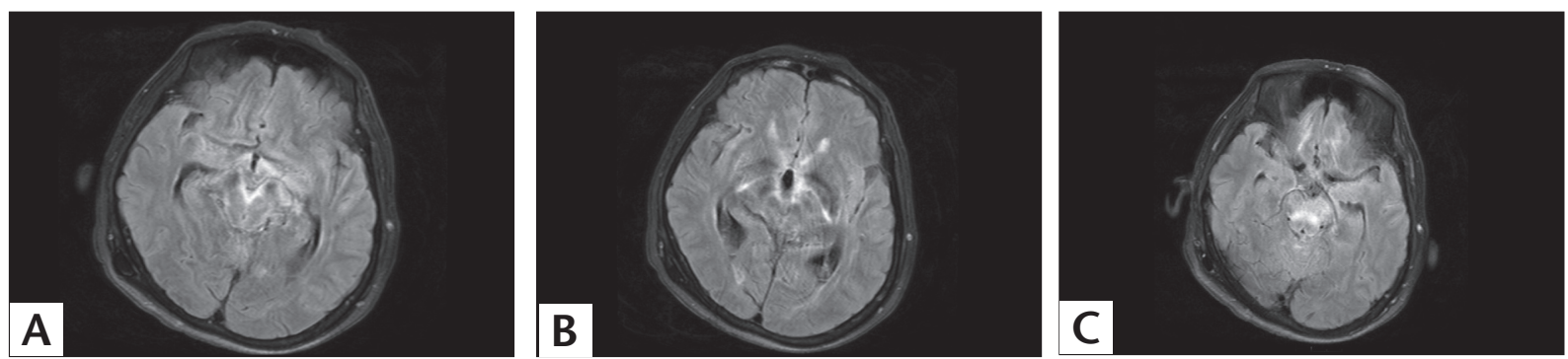

Figure 1. Axial FLAIR MRI images showing hyperintense areas involving brainstem and mesodiencephalic junction in a case of tuberculous meningitis, confirmed by the finding of Mycobacterium tuberculosis in cerebrospinal fluid cultures (A, B, C).
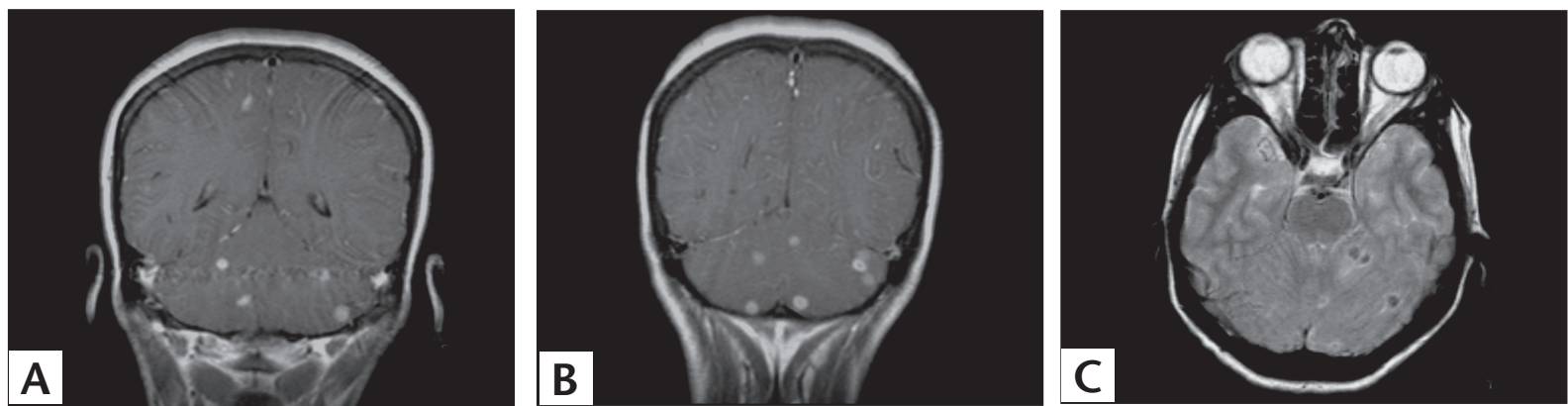

Figure 2. Multiple supra and infratentorial tuberculomas in a 54-year-old male with history of pulmonary tuberculosis. Tuberculomas are seen as multiple small ring enhancing lesions without peripheral edema in coronal postcontrast T1 weighted (A, B) and axial FLAIR MR images (C).

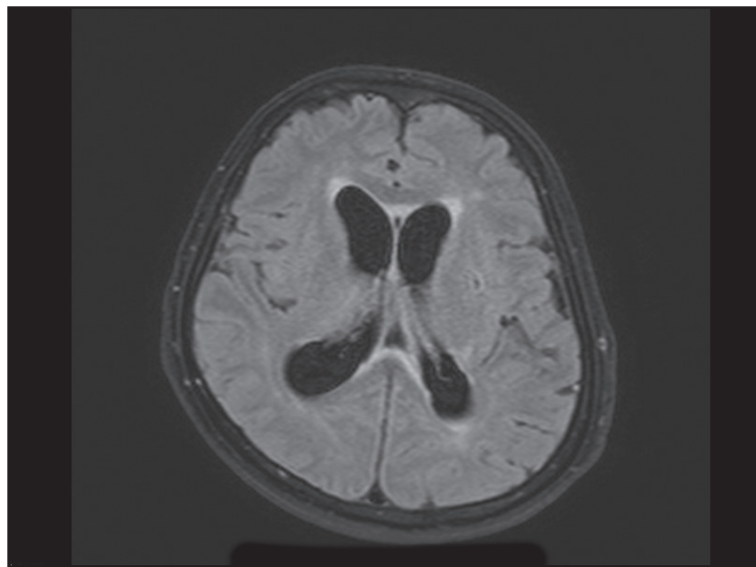

Figure 3. T1 weighted axial image in a patient with tuberculous meningitis demonstrating dilatation of the ventricles.

Figures 1-4 while a comparison of the percentages of the CT and MRI findings is presented in Table 1.

A two-month-long, continuous treatment regimen with isoniazid (INH), rifampicin (RIF), ethambutol (ETB), and pyrazinamide (PRZ) was initiated for all patients included in the study. Patients were subsequently treated with dual treatment re-

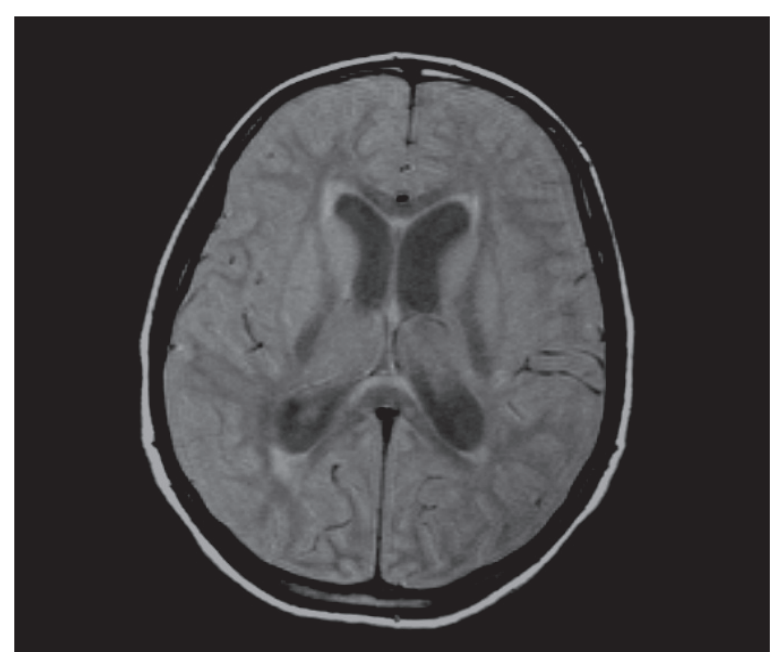

Figure 4. Ventriculitis with marked hydrocephalus in an axial FLAIR image of a 45-year-old female with tuberculous meningitis.

gimens consisting of INH and RIF for ten months. Furthermore, steroid therapy was administered in all patients except one who did not exhibit neurological symptoms at Stage 1.

Cranial nerve $(\mathrm{CN})$ involvement was detected in 7 (21.9\%) patients, all of whom expressed 
Table 1. CT and MRI of radiological appearances in the diagnosis of tuberculous meningitis

\begin{tabular}{lcc} 
Radiological findings & CT (\%) & MRI (\%) \\
\hline Basal exudates & 0 & 32.3 \\
Hydrosephalus & 34.4 & 45.2 \\
Gyral anhacement & 9.7 & 56.3 \\
Tuberculoma & 6.5 & 32.3 \\
Sylvian fissure exudate & 0 & 32.3 \\
Infarct & 6.3 & 25.8 \\
\hline CT: Computerized tomography, MRI: Magnetic resonance imaging.
\end{tabular}

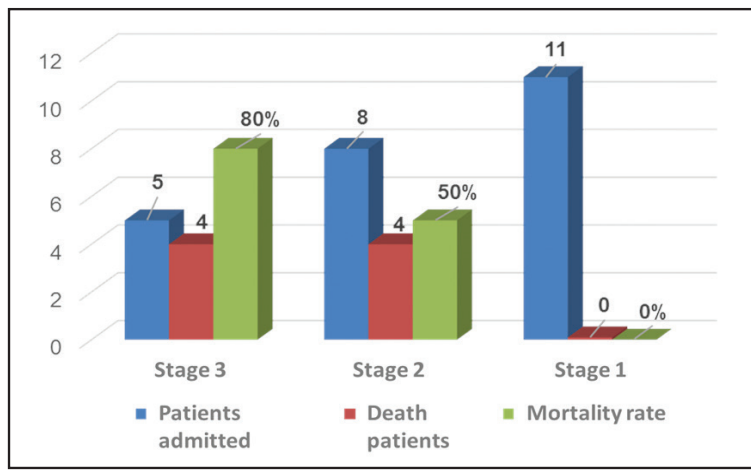

Figure 5. Neurological stage and mortality rate.

$\mathrm{CN} 6$ involvement. Only one patient additionally expressed $\mathrm{CN} 3$ and $\mathrm{CN} 4$ involvements.

The death rate of the patients involved in the study was $37.5 \%(n=12)$. Four of the $5(80 \%)$ patients who were at Stage 3 upon admission died, and the highest mortality rate was observed in this group. Of the eleven patients who were at Stage 1 upon admission, no deaths occurred, but $50 \%(n=8)$ of patients at Stage 2 upon admission died.

The correlation between mortality rates and stage levels is depicted in Figure 5.

\section{DISCUSSION}

Almost two billion people are infected with TB worldwide, while it is estimated that merely $10 \%$ of these individuals will clinically develop TBM. TB is the ninth-leading cause of death in the world; in 2016, 1.7 million people died from the TB. In Turkey, based on a review of the records from the last ten years, more than 12.000 new cases were reported each year ${ }^{[8]}$. Although many individuals are successfully treated, a large proportion of the deaths that occur can be prevented by early diagnosis and treatment. The high incidence of $\mathrm{TB}$ in a community leads to an increase in the incidence of CNS TB. TBM is the most common infectious disease in chronic CNS infections, and TB remains a serious health problem in developing countries ${ }^{[9]}$. In developed countries, TBM is an infection that specifically develops in HIV-infected individuals.

Adults aged between 25 and 45 years are most commonly affected of TBM worldwide $e^{[3,9-11]}$. Although the age range in our study was wider, it is nevertheless comparable with this data, with a mean age of 37.4 years.

TBM is the most significant cause of chronic CNS infections, especially in developing countries. Therefore, TBM patients' complaints are longer lasting compared to patients with bacterial meningitis $^{[2]}$. In our study, although patient complaints were shorter, they were consistent with chronic infection findings at a mean of approximately one month.

As noted in various studies, a patient's personal history of TB and one's close contact with a person infected with TB are both important risk factors ${ }^{[2]}$. These risk factors are both noticeable in our study, and for this reason, when TBM is suspected, the patient must be questioned for these two factors.

Fever and headache are the most common symptoms for both acute bacterial and TB meningitis. Physical examination findings including nuchal rigidity, Kernig signs, and Brudzinski signs were all positivity rates in our study were similar to findings of other studies. The occurrence of convulsions was a less common finding and was reported in $5(5.6 \%)$ patients in our study (while it has been reported to be as high as $36.6 \%$ in other studies conducted in Turkey).

The analysis of CSF in the diagnosis and follow-up of a meningitis patient must be performed unless it is contraindicated. According to classical TBM information, increased pressure, xanthochromic appearance, low glucose value, high protein value, low sodium value, and a cell count between 0 and $1000 / \mathrm{mm}^{3}$ in patients' CSF should be expected. CSF findings in our study are similar 
to those found in other studies reported in the related literature.

Medical history, examination findings, and CSF findings are very substantial for following up patients diagnosed with TBM although this information is insufficient for a definitive diagnosis. Despite the fact that a patient is diagnosed with meningitis based on this information, the bacillus must be documented as isolating TBM from the CSF and, as discussed above, a definitive diagnosis may not always be possible and/or may be rather time consuming to obtain.

In this study, we analyzed patients' results by determining five different radiologic abnormalities on imaging modalities that guide the diagnosis and course of TBM. We defined the radiological abnormalities as hydrocephalus, gyral enhancement, exudate in basal cisterns, exudate in sylvian fissure, tuberculoma, and infarction, and evaluated patients' CT and MRI results to detect these abnormal findings. As a result of the evaluation, the rate of detecting radio-pathological findings with MRI was generally superior to that of CT. It was observed that MRI may detect all these findings-which are valuable for the diagnosis of TBM-at a higher rate than that of CT. Tuberculoma, a marker that is specifically critical for TBM, was detected at a much higher rate by MRI, while two other quite significant findings (the exudates in basal cisterns and in a sylvian fissure) may be detected by MRI. CT, on the other hand, may not determine either finding in patients. At this point, MRI has proven to be a very important assistive diagnostic tool in both clinically diagnosed patients and in patients who have received a definitive diagnosis.

Other studies in the related literature have reported the mortality rate for $\mathrm{TBM}$ to be between $10 \%$ and $50 \%$ worldwide ${ }^{[10,11]}$. The mortality rate of $37.5 \%(n=12)$ determined by our study emphasizes once again that TBM is the most fatal type of $\mathrm{TB}$. The most important factor in the prognosis of TBM is a patient's neurological stage at the time of admission. In our study, no death occurred in Stage 1 patients, but the rate significantly increased in patients at Stages 2 and 3 , reaching $80 \%(n=5)$ in Stage 3 patients.
In conclusion, MRI has been a beneficial tool in the diagnosis of patients in our study. Many studies have been conducted to facilitate the direction of diagnosing diseases with important and diagnostic difficulties (e.g., TBM), and these studies attempt to determine diagnostic algorithms by revealing significant findings related to such diseases $^{[6]}$. We believe the inclusion of MRI in such algorithms may be beneficial due to its contribution toward identifying a disease's expression catching a disease's findings, as is supported by our study. In addition to these algorithms, MRI is a valuable method in every possible situation because it detects pathological findings in an early stage of determining a TBM diagnosis.

\section{CONFLICT of INTEREST}

The authors reported no conflict of interest related to this article.

\section{AUTHORSHIP CONTRIBUTIONS}

Concept/Design: IAK, RA

Analysis/Interpretation: İAK

Data Acquisition: IAK, RT, AND, CA

Writting: İAK, GC, RA

Critical Revision: RT, CA

Final Approval: RT, İAK

\section{REFERENCES}

1. World Health Organization (WHO). WHO Global Tubeculosis Report 2017. Access Date: 3 Novenber 2019 Available from: https://www.who.int/tb/publications/global_report/ gtbr2017_main_text.pdf

2. Thwaites $G$, Fisher M, Hemingway C, Scott G, Solomon T, Innes J, et al. British Infection Society guidelines for the diagnosis and treatment of tuberculosis of the central nervous system in adults and children. J Infect 2009;59(3):167-87.

3. Bhigjee Al, Padayachee $R$, Paruk $H$, Hallwirth-Pillay $K D$, Marais S, Connoly C. Diagnosis of tuberculous meningitis: clinical and laboratory parameters. Int I Infect Dis 2007;11(4):348-54.

4. Dendane T, Madani N, Zekraoui A, Belayachi J, Abidi K, Zeggwagh AA, et al. A simple diagnostic aid for tuberculous meningitis in adults in Morocco by use of clinical and laboratory features. Int J Infect Dis 2013;17(6):e461-5.

5. Misra UK, Kalita J, Roy AK, Mandal SK, Srivastava M. Role of clinical, radiological, and neurophysiological changes in predicting the outcome of tuberculous meningitis: a multivariable analysis. I Neurol Neurosurg Psychiatry 2000;68(3):300-3. 
6. Trivedi R, Saksena S, Gupta RK. Magnetic resonance imaging in central nervous system tuberculosis. Indian J Radiol Imaging 2009;19(4):256-65.

7. Bomanji JB, Gupta N, Gulati P, Das CJ. Imaging in tuberculosis. Cold Spring Harb Perspect Med 2015;5(6):a017814.

8. Tüberküloz Daire Başkanlığı istatistiksel Verileri. Available date: 3 October 2019. Available from: http://www.thsk. gov.tr/component/k2/353-istatiksel-veriler/tuberkuloz-daire-baskanligi-istatiksel-verileri.html

9. Cherian A, Thomas SV. Central nervous system tuberculosis. Afr Health Sci 2011;11(1):116-27.

10. Yüce $P$, Çelik $I$, Kalkan A, Demirdağ K, Cihangiroğlu M. Tüberküloz menenjit: 30 olgu bildirisi. FLORA 2003;8(3):22631.
11. Kent SI, Crowe SM, Yung A, Lucas CR, Mijch AM. Tuberculous meningitis: a 30-year review. Clin Infect Dis 1993;17(6):987-94.

\section{Yazıșma Adresi/Address for Correspondence}

Uzm. Dr. İrem AKDEMIR KALKAN

Ankara Üniversitesi Tıp Fakültesi,

İbni Sina Hastanesi,

İnfeksiyon Hastalıkları ve

Klinik Mikrobiyoloji Anabilim Dal,

Ankara-Türkiye

E-posta: iremakd@yahoo.com 